\title{
Drought assessment in the northern region of Colombia using the Standardized Precipitation Index (SPI): a case study in the department of La Guajira
}

Luis Díaz Chávez ( $\square$ luisdiazc@uniguajira.edu.co)

Universidad de La Guajira https://orcid.org/0000-0002-7484-1836

Ana Patricia Espinosa Romero

Universidad de La Guajira

Jairo Rosado Vega

Universidad de La Guajira

\section{Research Article}

Keywords: Droughts, Standardized Precipitation Index (SPI), La Guajira, operational characteristics, temporal trends

Posted Date: November 1st, 2021

DOI: https://doi.org/10.21203/rs.3.rs-1029721/v1

License: (c) (1) This work is licensed under a Creative Commons Attribution 4.0 International License.

Read Full License 
Drought assessment in the northern region of Colombia using the Standardized Precipitation Index (SPI): a case study in the department of La Guajira

\section{Luis Díaz Chávez}

Master in Geographical Information Technologies, Environmental Engineer. Institute of Environmental Studies and Water Supply - INESAG, University of La Guajira. Riohacha, Colombia. Contact: luisdiazc@uniguajira.edu.co

ORCID: https://orcid.org/0000-0002-7484-1836

\section{Ana Patricia Espinosa Romero}

Master in Rural Development, Specialist in Environmental Management and Sustainable Development, Environmental Engineer. Director of the Environmental Engineering Program, University of La Guajira. Riohacha, Colombia. Contact: apespinosa@uniguajira.edu.co

ORCID: https://orcid.org/0000-0002-5964-9512

\section{Jairo Rosado Vega}

Biologist. Associate Professor at the University of La Guajira, School of Engineering. University of Guajira. Riohacha, Colombia. Contact: jairorosado@uniguajira.edu.co

ORCID: https://orcid.org/0000-0002-0116-7211

\section{Abstract}

The objective of this study was to assess droughts in the department of La Guajira, Columbia, on the basis of their operational characteristics. Droughts were assessed using the Standardized Precipitation Index (SPI) at three- and six-month aggregation periods (SPI-3 and SPI-6), and their operational characteristics were analyzed by the run theory and via analysis of temporal trends using the modified Mann-Kendall (MMK) test. The results indicated that droughts were most frequent in La Guajira between 1995 and 2004. The occurrence of droughts was most accurately identified by SPI-6. It was observed that the central, southern, and western areas of the department had droughts of greater duration, severity, and intensity. The MMK test shows negative (decreasing) temporal trends at significance levels $\alpha$ between 0.1 and 0.01 in $6.12 \%$ of the meteorological stations located in the central and southern areas of La Guajira. These results support the conclusion that droughts are recurrent events in the department of La Guajira as a result of the arid and semi-arid climate prevalent in significant portions of the department's land area. This elucidates the vulnerability of agriculture and livestock in such areas that are prone to droughts of greater duration, severity, and intensity.

Keywords: Droughts, Standardized Precipitation Index (SPI), La Guajira, operational characteristics, temporal trends. 
39 Droughts are extreme climatic events that occur worldwide, especially in arid and semi-arid regions 40 (Touchan et al. 2005). They are characterized by a reduction in rainfall over a prolonged period of time and are currently a major concern owing to their negative impacts on ecosystems, agricultural production ( $\mathrm{Yu}$ et al. 2014), the environment, and people due to climate change, changes in land use, degradation of natural resources, and impact on social and economic systems (Thomas et al. 2015; Touchan et al. 2005).

Drought is primarily caused by deficient rainfall, and the duration, distribution, and intensity of this deficiency in relation to existing water storage, demand, and usage impacts its probability and intensity (Asadi Zarch et al. 2015). Three well-known categories of droughts have been recorded in the literature: (1) meteorological drought, (2) hydrological drought, and (3) agricultural drought. Meteorological drought is defined as the absence of rainfall in a region for a particular period of time (Belal, El-Ramady, Mohamed and Saleh, 2012; Mishra and Singh, 2010; Thomas et al. 2014). Hydrological drought follows a meteorological drought, and is defined as a deficit in the volume of surface and groundwater supply available to a particular water resource management system that is responsible for fulfilling the demands of an area (Thomas et al. 2014). Finally, an agricultural drought occurs when there is insufficient soil moisture and, consequently, leads to crop yield failures (Karabulut, 2015; Luetkemeier, Stein, Drees and Liehr, 2017; Mishra and Singh, 2010).

A drought is generally assessed using drought indices. Many such indices are available globally, and each has its own strengths and weaknesses. The most notable ones are the Palmer Drought Severity Index (Palmer, 1965), Standardized Precipitation Index (Mckee et al. 1993), Standardized Precipitation Evapotranspiration Index (Vicente-Serrano et al., 2010), and Effective Drought Index (Byun and Wilhite, 1999), among others (Mishra and Singh, 2010). The Standardized Precipitation Index (SPI) proposed by Mckee et al. (1993) has become popular worldwide as it can be used for the assessment of different time scales and supports analysis of different drought categories. Therefore, SPI is considered to be among the most robust and effective drought indices. Furthermore, as it only requires rainfall data, it can be calculated with greater ease compared to other, more complex, indices. It also supports the comparison of drought conditions in different regions and for different time scales (Caloiero, 2017).

Several studies that investigated various drought-related issues have demonstrated the wide applicability of SPI in the United States (Logan et al. 2010; Mitra and Srivastava, 2017), Asia (Sönmez et al. 2005; Shahid and Behrawan, 2008; He et al. 2015; Nam et al. 2015; Zuo et al. 2016; Dahal et al. 2016; Ghosh and Srinivasan, 2016; Rahman and Lateh, 2016; Yan et al. 2017), Africa (Guenang and Mkankam Kamga, 2014; Luetkemeier et al. 2017; Manatsa et al. 2010), Europe (Ashraf and Routray, 2015; Bonaccorso et al. 2015; Caloiero, 2017; Ionita et al. 2016; Livada and Assimakopoulos, 2007), and Latin America (Benitez and Domecq, 2014; Guimarães et al. 2017; Mendoza and Puche, 2007; Rivera et al. 2007; Rivera and Penalba, 2014; Toná Juliani and Passos Okawua, 2017). 
The existing scientific literature on drought as a natural hazard is limited in Colombia. Significant contributions include an important local-scale investigation by Loaiza et al. (2015) to characterize meteorological droughts in the Dagua river basin, studies on the spatiotemporal analysis of droughts and their relationship with the warm phase of the El Niño/La Niña-Oscilación del Sur (ENSO) climate variability phenomenon in the city of Cali (Loaiza-Cerón et al. 2020), comparisons of regional droughts in the Sumapaz and Lebrija basins based on their Severity-Duration-Frequency curves (Rojas and DíazGranados, 2018), and technical reports from the Institute of Hydrology, Meteorology and Environmental Studies (IDEAM) to understand droughts in the country (Gómez, 2016; Hurtado, 2012; Mayorga and Hurtado, 2006) following the recommendation of the World Meteorological Organization (WMO) to use the SPI for characterizing droughts.

Geographically, the department of La Guajira, in Colombia, is among the areas that are most sensitive to the effects of climate change in South America, and is especially sensitive to increased intensity and frequency of hydrometeorological hazards such as droughts, which pose a threat to human life and socioeconomic activities. However, there are no studies assessing droughts as a natural hazard in the department and which contribute to its understanding from an operational perspective.

Therefore, considering the unique characteristics of the department of La Guajira due to the arid and semiarid climate in a large proportion of its territory, and the presence of highly vulnerable areas with waterdependent human life and socioeconomic activities, this study aimed to assess droughts in the region using SPI and to define them in terms of their operational characteristics: duration, severity, and intensity.

\section{Materials and methods}

\subsection{Study area}

The department of La Guajira is located in the northernmost region of the Republic of Colombia and South America (CORPOGUAJIRA, 2012) on a peninsula of the same name, and is part of the Caribbean region. It is bordered to the north and west by the Caribbean Sea, to the east by the Bolivarian Republic of Venezuela and the Gulf of Venezuela, to the south by the department of Cesar, and to the southwest by the department of Magdalena (Fig. 1a).

Geographically, La Guajira is located between $10^{\circ} 23^{\prime} \mathrm{N}$ and $12^{\circ} 28^{\prime} \mathrm{N}$, and $71^{\circ} 06^{\prime} \mathrm{W}$ and $73^{\circ} 39^{\prime} \mathrm{W}$, and occupies an area of approximately $20,670 \mathrm{~km}^{2}$. It has an arid, dry, and tropical climate with high temperature. Rainfall is mainly governed by the movement of the trade winds, which create conditions of severe dryness and aridity when they pass through the northern mountains and the great plains, and cause rainfall upon collision with the Sierra Nevada de Santa Marta mountain range. As a result, rainfall increases from northeast to southwest with mean annual values ranging from $200 \mathrm{~mm}$ in the northeast of La Guajira to approximately 2,000 $\mathrm{mm}$ in the southwest regions, near the Sierra Nevada de Santa Marta. 

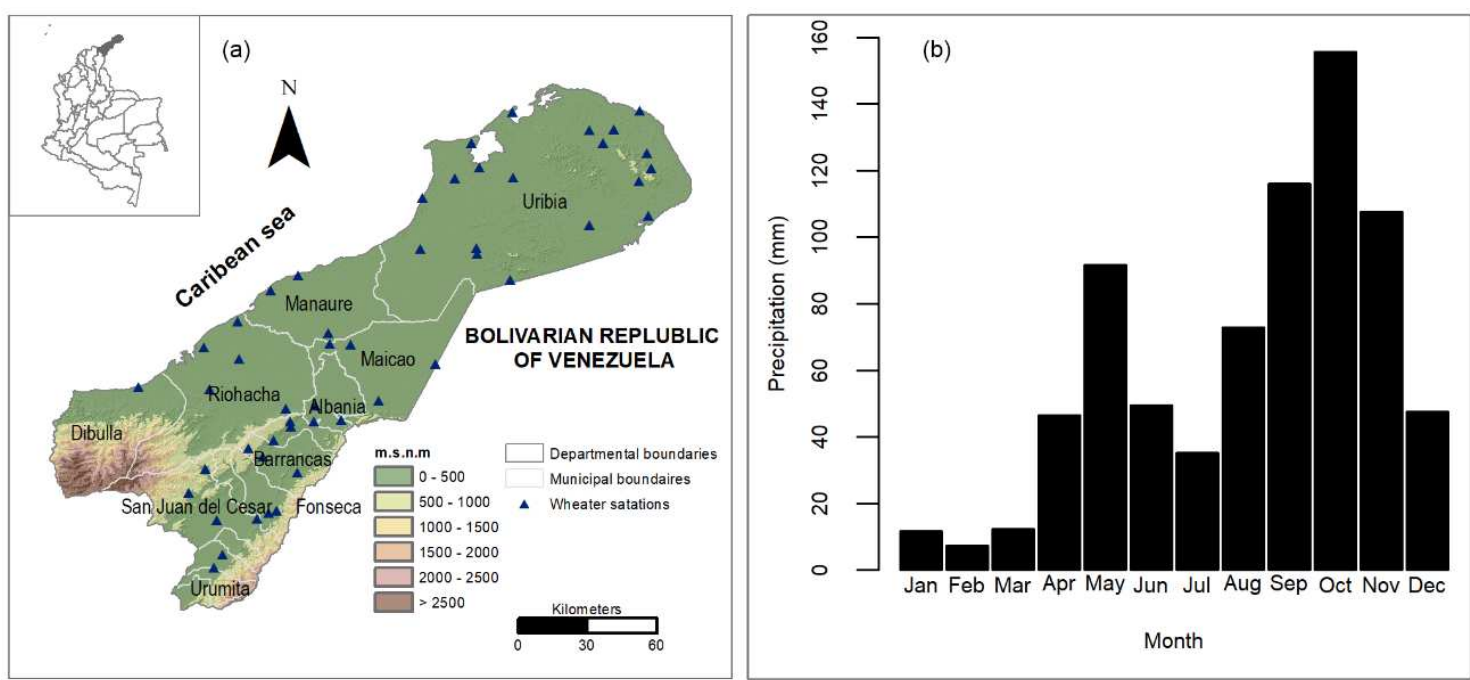

Fig. 1 Study area: a) Location of the department of La Guajira and spatial distribution of selected climatological stations; b) Monthly distribution of historical mean rainfall in the selected climatological stations

The historical records of total monthly rainfall for the period from 1985 to 2015 (31 years) in 49 meteorological stations (Fig. 1a) were provided by the IDEAM (http://www.ideam.gov.co/) to analyze droughts in the department of La Guajira. One of the limitations of using rainfall data of the department was the missing data in the time series of some stations; therefore, a selection criteria was imposed wherein only stations with less than $10 \%$ of missing data in their records for the selected study period were used (Dahal et al. 2016). The imputation of missing data was carried out by using the mean value of rainfall totals of the same month from previous and subsequent years (He et al. 2011; Rahman and Lateh, 2016).

\subsection{Standardized Precipitation Index (SPI)}

Drought conditions were assessed using SPI at three- and six-month periods, which reflect soil moisture conditions and impact on crop production, i.e., parameters that were associated with the assessment of agricultural droughts (Caloiero, 2017). To calculate SPI, rainfall records at each station were fitted to a probability distribution function, specifically, the gamma function (Ashraf and Routray, 2015; Caloiero, 2017; Chang et al. 2016; He et al. 2015; Mansouri et al. 2013). This was then transformed to a standard normal distribution, such that the mean SPI was zero and represented the normal moisture conditions of the study area, thus indicating the area's mean rainfall. Therefore, SPI $<0$ reflects drought conditions in the area of interest and SPI $>0$ indicates an excess of water (Chang et al. 2016). 
152

153

154

155

156

157

158

159

160

161

162

163

164

165

166

167

168

169

170

171

172

173

174

175

176

177

The mathematical procedure for calculating SPI is briefly described below. Initially, the historical records of total rainfall for each station at the selected time scale were fitted to a gamma probability distribution function:

$$
g(x)=\frac{1}{\beta^{\alpha} \Gamma(\alpha)} x^{\alpha-1} e^{-x / \beta}, \quad x>0
$$

Where, $\alpha>0$ is a shape parameter, $\beta>0$ is a scale parameter, and $x>0$ is the rainfall. $\Gamma(\alpha)$ is the gamma function, which is defined as:

$$
\Gamma(\alpha)=\int_{0}^{\infty} y^{\alpha-1} e^{-y} d y
$$

The unknown parameters $\alpha$ and $\beta$ were estimated using the maximum likelihood approximation of Thom (1966) for each season, each time scale (three and six months), and each month of the year as shown below:

$$
\hat{\alpha}=\frac{1}{4 A}\left(1+\sqrt{1+\frac{4 A}{3}}\right)
$$

$$
\hat{\beta}=\frac{\bar{x}}{\hat{\alpha}}
$$

Where,

$$
A=\ln (\bar{x})-\frac{1}{n} \sum_{1=1}^{n} \ln \left(x_{i}\right)
$$

Here, $n$ is the number of rainfall observations, $\bar{x}$ is the mean rainfall for the time scale of interest, and $A$ is a measure of the asymmetry of the distribution (Husak et al. 2007).

Integrating the probability distribution function with respect to $x$ and inserting the estimated parameters $\hat{\alpha}$ and $\hat{\beta}$ produces the following expression for the cumulative probability $G(x)$ of an observed rainfall event occurring in a given month and time scale:

$$
G(x)=\frac{1}{\hat{\beta}^{\hat{\alpha}} \Gamma(\hat{\alpha})} \int_{0}^{x} x^{\hat{\alpha}} e^{-x / \hat{\beta}} d x
$$


179 Since the gamma distribution is undefined for rainfall values of $x=0 ; G(x)$ should be modified as

180 follows for considering the zero values occurring in the rainfall records:

181

182

183

184

185

186

187

188

189

190

191

192

193

194

195

196

197

198

199

200

201

202

203

204

205

206

$$
H(x)=q+(1-q) G(x)
$$

Where $q$ is the probability that $x=0$ (rainfall equal to zero) occurs, calculated as the quotient of the number of zeros in the precipitation series $(m)$ and the total number of observations $(n)$ (Thom, 1966).

Finally, the cumulative probability function $H(x)$ is transformed to a variable $Z$ that follows a standard normal distribution with zero mean and standard deviation equal to unity, which represents the SPI value, using the approximate conversion suggested by Abramowitz and Stegun (1965):

$$
\begin{array}{ll}
Z=S P I=-\left(t-\frac{c_{0}+c_{1} t+c_{2} t^{2}}{1+d_{1} t+d_{2} t^{2}+d_{3} t^{3}}\right) & 0<H(x) \leq 0.5 \\
Z=S P I=+\left(t-\frac{c_{0}+c_{1} t+c_{2} t^{2}}{1+d_{1} t+d_{2} t^{2}+d_{3} t^{3}}\right) & 0.5<H(x)<1.0
\end{array}
$$

Where,

$$
\begin{array}{cc}
t=\sqrt{\ln \left(\frac{1}{(\ln H(x))^{2}}\right)} & 0<H(x) \leq 0.5 \\
t=\sqrt{\ln \left(\frac{1}{(1-\ln H(x))^{2}}\right)} & 0.5<H(x)<1.0
\end{array}
$$

$c_{0}=2.515517, d_{1}=1.432788$

$c_{1}=0.802853, d_{2}=0.189269$

$c_{2}=0.010328, d_{3}=0.001308$

In order to optimize the calculation of SPI for all climatological stations at the department of La Guajira and at the selected time scales, the SPEI package (Begueria et al. 2017) of R v3.5.1 (R Core Team, 2018) was used. 

information on SPI can be found in Mckee et al. (1993), Hayes et al. (1999), and Lloyd-Hughes and Saunders (2002).

Table 1. Drought categories defined by SPI

\begin{tabular}{cll}
\hline \multicolumn{1}{c}{ SPI } & Drought category & $\begin{array}{l}\text { Probability of } \\
\text { occurrence (\%) }\end{array}$ \\
\hline$-1.0 \leq S P I<0.0$ & Mild drought & 34.1 \\
$-1.5 \leq S P I<-1.0$ & Moderate drought & 9.2 \\
$-2.0 \leq S P I<-1.5$ & Severe drought & 4.4 \\
$S P I<-2.0$ & Extreme drought & 2.3 \\
\hline
\end{tabular}

212

213

214

215

216

217

218

219

220

221

222

223

224

\subsection{Operational characteristics of droughts}

The operational characteristics of droughts were determined by the run theory proposed by Yevjevich (1967). A run is defined as a portion of a one-variable time series — in this case the SPI time series-in which each value is above or below a given threshold (Fig. 2). According to the classification of droughts shown in Table 1, the threshold level selected to define droughts is -1 . Therefore, based on Fig. 2, the drought characteristics were defined as follows: (1) duration of a drought $(D)$ is the time elapsed between the beginning and the end of a drought, with SPI values continuously below the threshold; (2) drought severity (magnitude) $(S)$ is the dimensionless sum of SPI values below the threshold during the drought event; and (3) drought intensity $(I)$ is the mean severity during the drought event and is calculated as the severity divided by the duration.

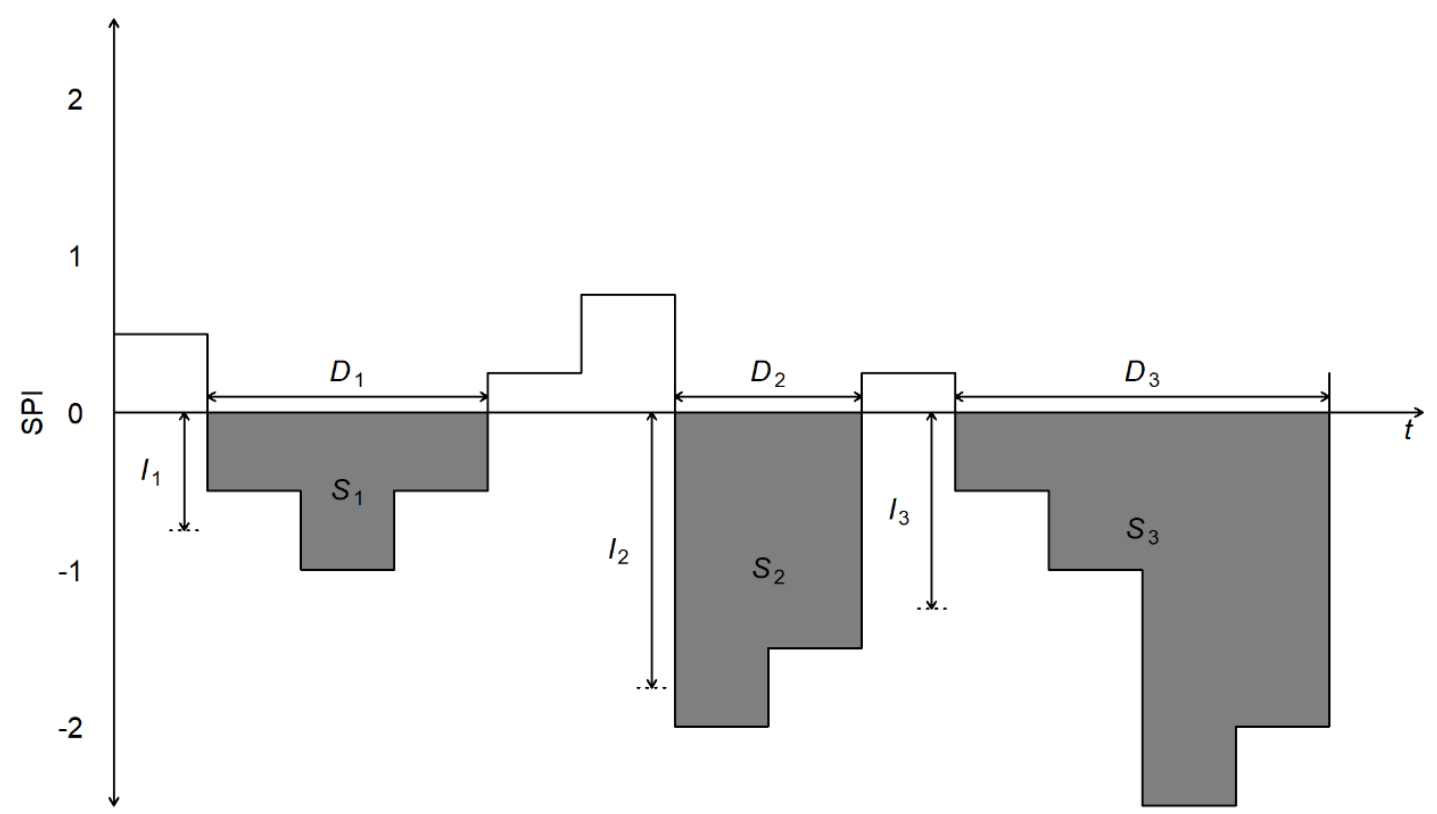

Fig. 2 Drought characteristics using the run theory of Yevjevich (1967) 
The spatial distribution of droughts in the department of La Guajira was mapped using the inverse distance weighted (IDW) interpolation method (Manikandan and Tamilmani, 2015; Parker et al. 2009; Yuan et al.

232

233

234

235

236

237

238

239

240

241

242

243

244

245

246

247

249

250

251

252

253

254

255

256

257

258

259 2015). The IDW interpolation method assumes that the values of the variable to be processed (drought) in areas with no observed data is a mean of the inverse weighted distance of the observed values of the variable at sampling points located in the vicinity; therefore, the closer the points with observed data are to the estimation areas, the more similar the values will be to those of more distant areas. The spatial interpolation of SPI data in the department of La Guajira using the IDW method was performed with GIS (ArcGis Desktop 10.5).

The temporal trends of drought in different meteorological stations of La Guajira were analyzed using the Mann-Kendall (MK) test, (Mann, 1945; Kendall, 1975); this a non-parametric rank-based test that is widely used for detecting trends in time series of hydrological variables and drought indicators (Ashraf and Routray, 2015; Chang et al. 2016; Dahal et al. 2016; Hong et al. 2014). This test considers that the MK trend test statistic for a series of observations is calculated by

5

$$
S=\sum_{i<j} \operatorname{sng}\left(x_{j}-x_{i}\right)
$$

Where,

$$
\operatorname{sng}\left(x_{j}-x_{i}\right)= \begin{cases}1, & x_{i}<x_{j} \\ 0, & x_{i}=x_{j} \\ -1, & x_{i}>x_{j}\end{cases}
$$

Subsequently, under the hypothesis that the observations are independent and randomly ordered or identically distributed, the statistic $S$ tends to be normally distributed when $n$ is large, with mean $E(S)=0$ and variance given by

$$
\operatorname{Var}(S)=\frac{n(n-1)(2 n+5)}{18}
$$

Therefore, the significance of the trends is assessed by comparing the standardized statistical test $Z=S / \sqrt{\operatorname{Var}(S)}$ with the standard normal distribution at the desired level of significance. Hence, the hypothesis of no significant trend is rejected when $|Z|>Z_{1-\alpha / 2}$. Positive $Z$ values indicate an increase in the trend and vice versa (Ashraf and Routray, 2015). 
However, the efficacy of the MK test is reduced by the existence of autocorrelation in the time series, expressed as disturbances in the variance of $S$. For this reason, Hamed and Rao (1998) proposed the modified Mann-Kendall (MMK) test as a procedure that considers the existence of autocorrelation in the time series and removes its influence on trend detection by using the autocorrelation coefficients at a lag $i$ $\left(\sigma_{s}(i)\right)$ that are significantly different from zero at a level of significance of 0.05 to calculate the modified variance of $S$, which is given by:

Where 'Cor' is a correction given to the autocorrelation of the time series calculated as
The MMK test for the significance of trends in SPI time series in this study was analyzed at a level of significance of 0.05 using the modifiedmk library (Marx, 2012) of R v3.5.1 (R Core Team, 2018).

\section{Results and discussion}

\subsection{Characterization of drought events that occurred between 1985 and 2015.}

The time series analysis of total monthly rainfall in the 49 meteorological stations for 1985-2015 revealed the temporal variability of drought events that occurred in the department of La Guajira during this period. Fig. $3 a$ and Fig. $3 b$ show the distribution of the number of identified drought events in the meteorological stations during the subperiods of 1985-1994, 1995-2004, and 2005-2015 for different drought categories according to SPI-3 and SPI-6, respectively. Note that the subperiod of 1995-2004 had the highest number of drought events for all categories, according to SPI-3. Similar results were obtained for SPI-6, except for moderate droughts, for which the highest number of drought events occurred in the subperiod of 20052015 .

These results correspond to those obtained by IDEAM (2016) in a study which concluded that the highest frequency of droughts with important and lasting territorial effects occurred in the Colombian-Caribbean region, specifically, in La Guajira during 1991-92, 1997-98, 2001, and 2009. Additionally, there were other, smaller drought events of lower intensity or duration during 1982-83, 1986-1987, and 2002-2003. 

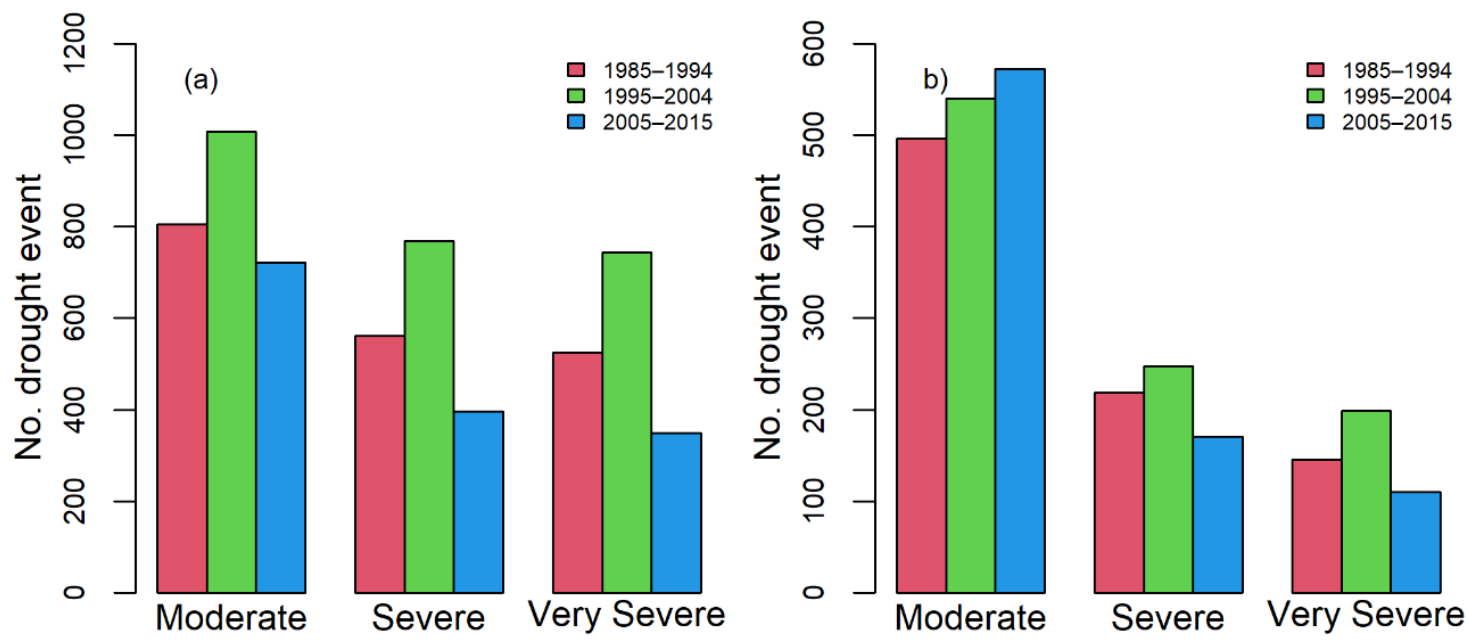

296

297

298

299

300

301

302

303

304

305

306

307

Fig. 3 Occurrence of drought events in the subperiods of 1985-1994, 1995-2004, and 2005-2015

according to: (a) SPI-3 and (b) SPI-6

A total of 8,081 drought events were identified in the department of La Guajira between 1985 and 2015. Of these, 5,380 and 2,701 correspond to droughts identified by SPI-3 and SPI-6, respectively, representing $29.5 \%$ and $14.8 \%$ of the total number of possible drought events $(18,229)$ during the study period.

The temporal variations of the mean occurrence of drought events in La Guajira for the temporal aggregations of SPI-3 and SPI-6 are illustrated in Fig. 4. It was observed that the droughts assessed by SPI3 exhibited higher frequencies of occurrence compared to SPI-6. However, the droughts assessed by SPI-6 were of longer duration and greater severity and intensity.
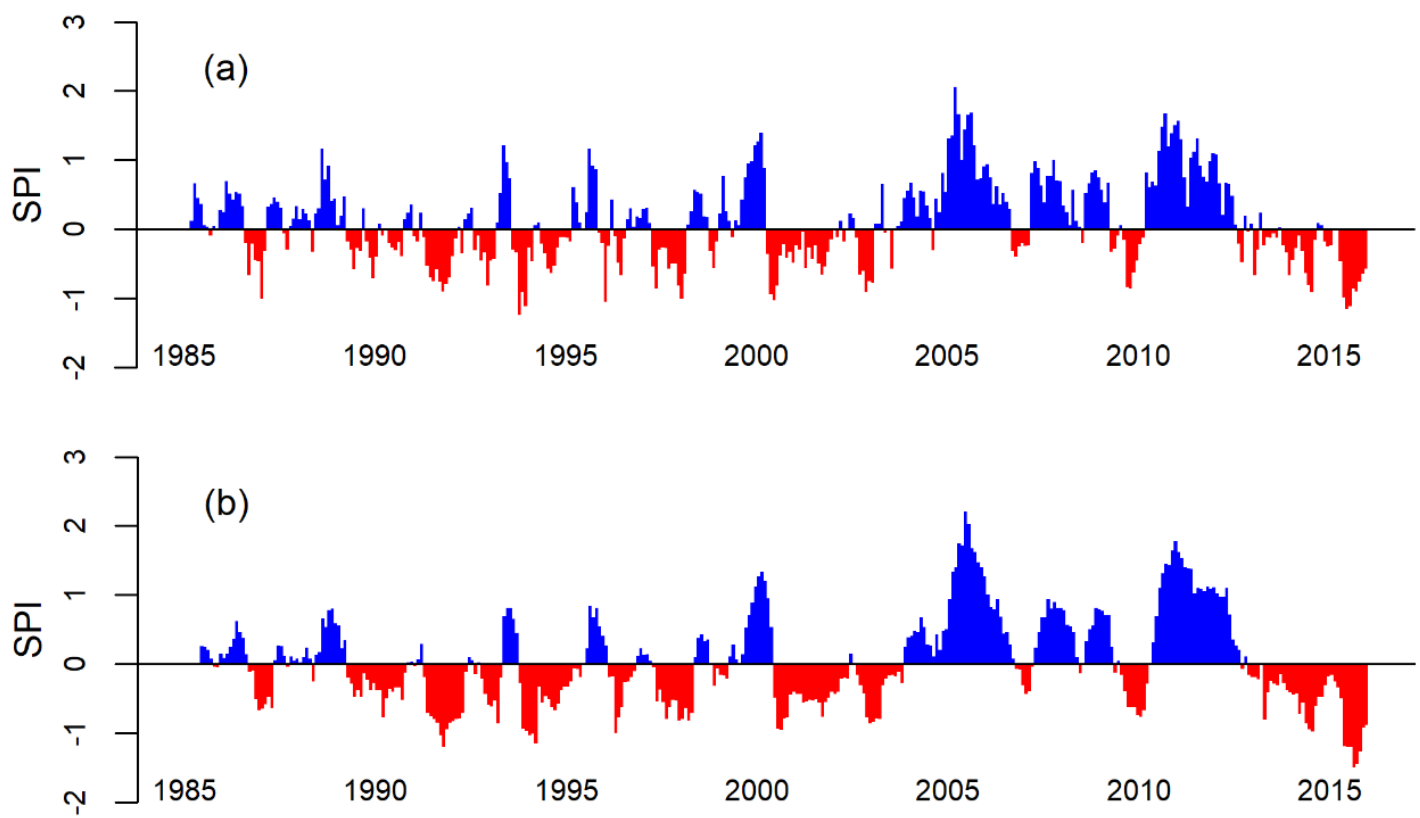

309 Fig. 4 Temporal variability of the mean occurrence of droughts in the department of La Guajira during the period of 1985-2015 for: (a) SPI-3 and (b) SPI-6 
312 Comparison of the temporal aggregations of SPI-3 and SPI-6 shows that the department of La Guajira is 313 predominantly characterized by the occurrence of frequent and moderate droughts. SPI-3 values show high 314 fluctuations about the zero line, indicating that droughts in La Guajira assessed by SPI-3 were mostly caused 315 by short-term rainfall variations. Conversely, SPI-6 shows greater stability, and its values show less 316 variation about the zero line and a greater smoothness in the time series, Therefore, SPI-6 is considered a 317 better indicator of seasonal droughts in the department of La Guajira. Although SPI-3 accurately reflects 318 the changes in rainfall for a particular month, and, consequently, the onset and duration of a drought event, 319 it is not the optimal temporal aggregation to characterize the persistence of droughts. In contrast, SPI-6 320 identifies fluctuations in rainfall and the persistence of drought events; however, when compared to SPI-3, 321 it is less reliable in identifying their onset and termination (Chang et al. 2016; Manikandan and Tamilmani, 322 2015).

\subsection{Operational characteristics of droughts that occurred between 1985 and 2015.}

With regards to the main operational characteristics of droughts, the distribution of the mean and maximum values of drought duration for all events occurring in the study area during the period of 1985-2015 — based on SPI-3 temporal aggregations - indicate that droughts generally affect the entire territory of the department of La Guajira (Fig. 5). However, droughts with the longest mean duration (67-108 days) were found to occur in the northern, southern, and western areas of the department (Fig. 5a). It was also evident that droughts of maximum duration (200-330 days) occurred in the southern and western areas of the department (Fig. 5b). On the contrary, the results of the SPI-6 temporal aggregation show that droughts of greater mean (106-204 days) and maximum (372-840 days) duration occurred in the central, southern, and western areas of the department of La Guajira as shown in Fig. 5c and Fig. 5d, respectively. 

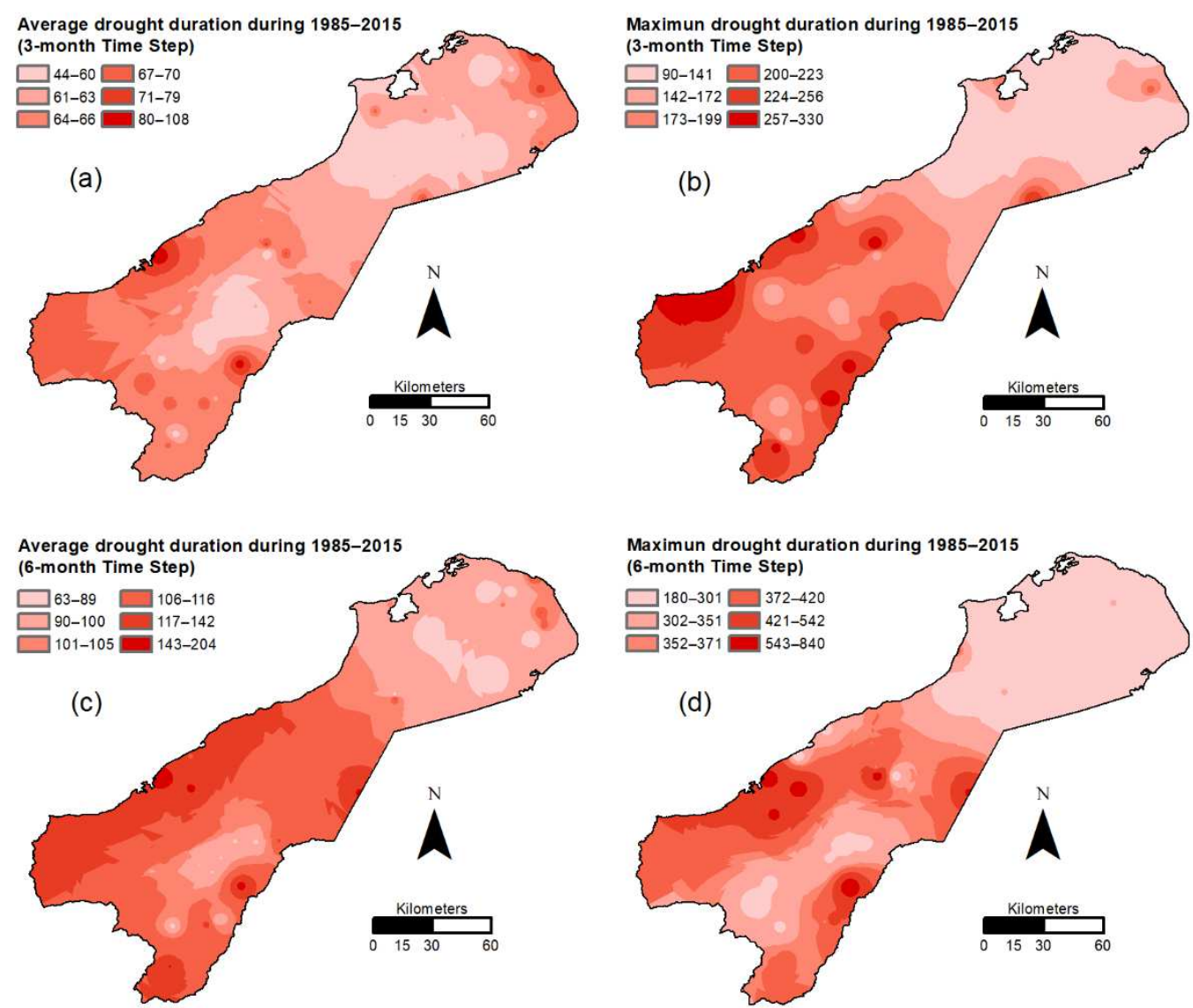

Fig. 5 Spatial distribution of drought duration in the department of La Guajira during the period of 1985-

In agreement with the results obtained for spatial distribution of drought duration in the department of La Guajira during the period of 1985-2015, it was observed that the greatest values of mean (3.39-5.84) and maximum (13.65-31.48) drought severity occurred in the central, southern, and western areas of the department for SPI-3 (Fig. 6a and Fig. 6b). Similar results were observed for mean (5.50-11.56) and maximum (21.46-54.05) severity, as shown in Fig. 6c and Fig. 6d, respectively. However, the SPI-6 temporal aggregation results show higher absolute mean and maximum severity values compared to those obtained from SPI-3. Furthermore, they also show a more focused spatial distribution pattern within the areas affected by droughts. 

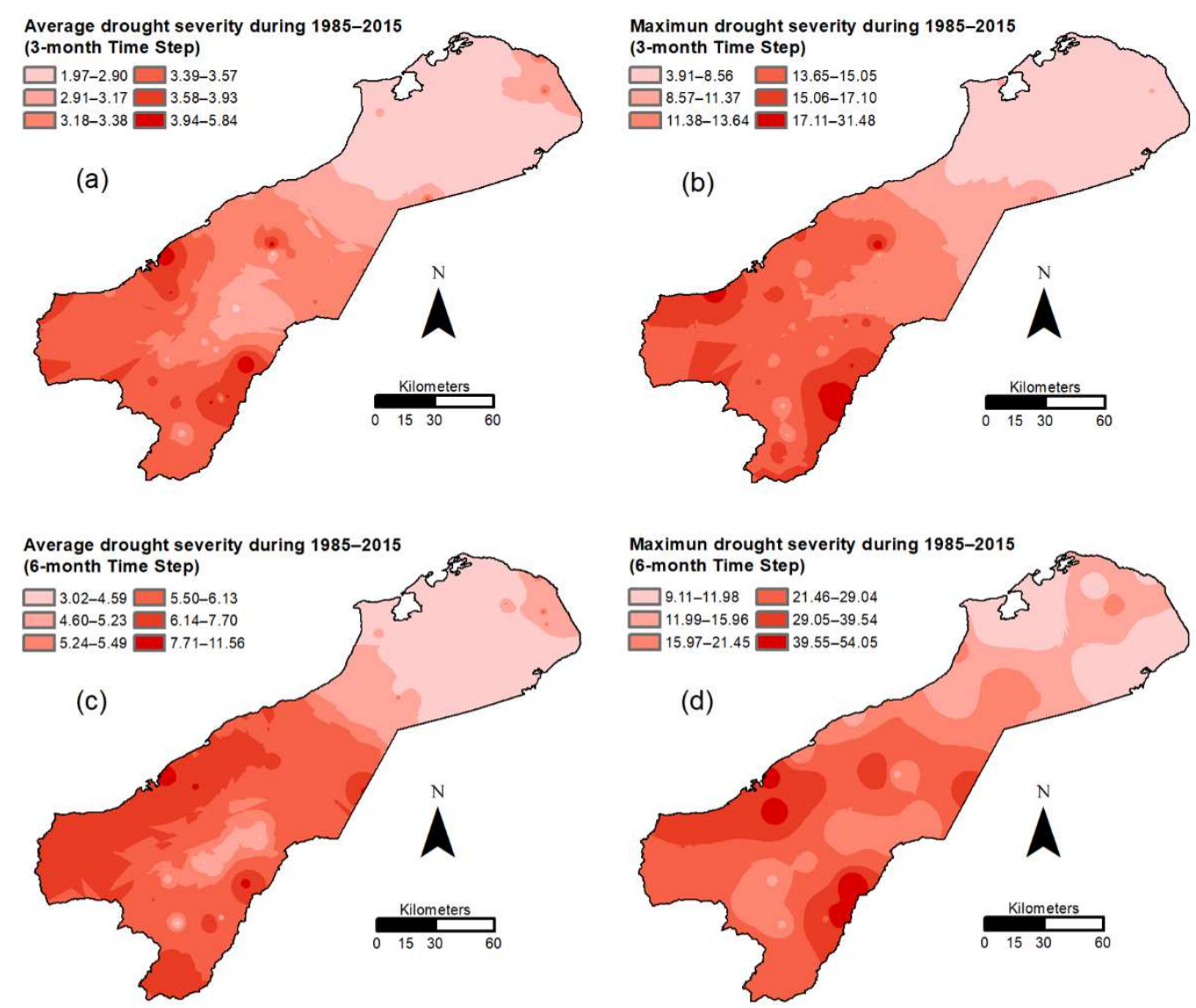

Fig. 6 Spatial distribution of drought severity in the department of La Guajira during the period of 1985-

Finally, when considering the intensity of droughts occurring in the department of La Guajira during the study period (Fig. 7), it was observed that the highest mean (1.41-1.61) and maximum (2.33-4.33) intensities for SPI-3 were predominantly distributed in the central, southern, and western areas of the department (Fig. 7a and Fig. 7b, respectively). Similar results, albeit in a more focused manner, were obtained for the greatest mean (1.39-1.57) and maximum (1.93-3.28) values for SPI-6 temporal aggregation, as shown in Fig. 7c and Fig. 7d, respectively. It is notable that, despite the notorious spatial association, SPI-3 showed slightly higher values of mean and maximum intensity than those obtained for SPI-6. As this characteristic is derived from the previously discussed results regarding duration and severity, and has an inverse relationship with drought duration, it reaffirms the conclusion that these areas of the department were the most affected by droughts of high duration and severity. 

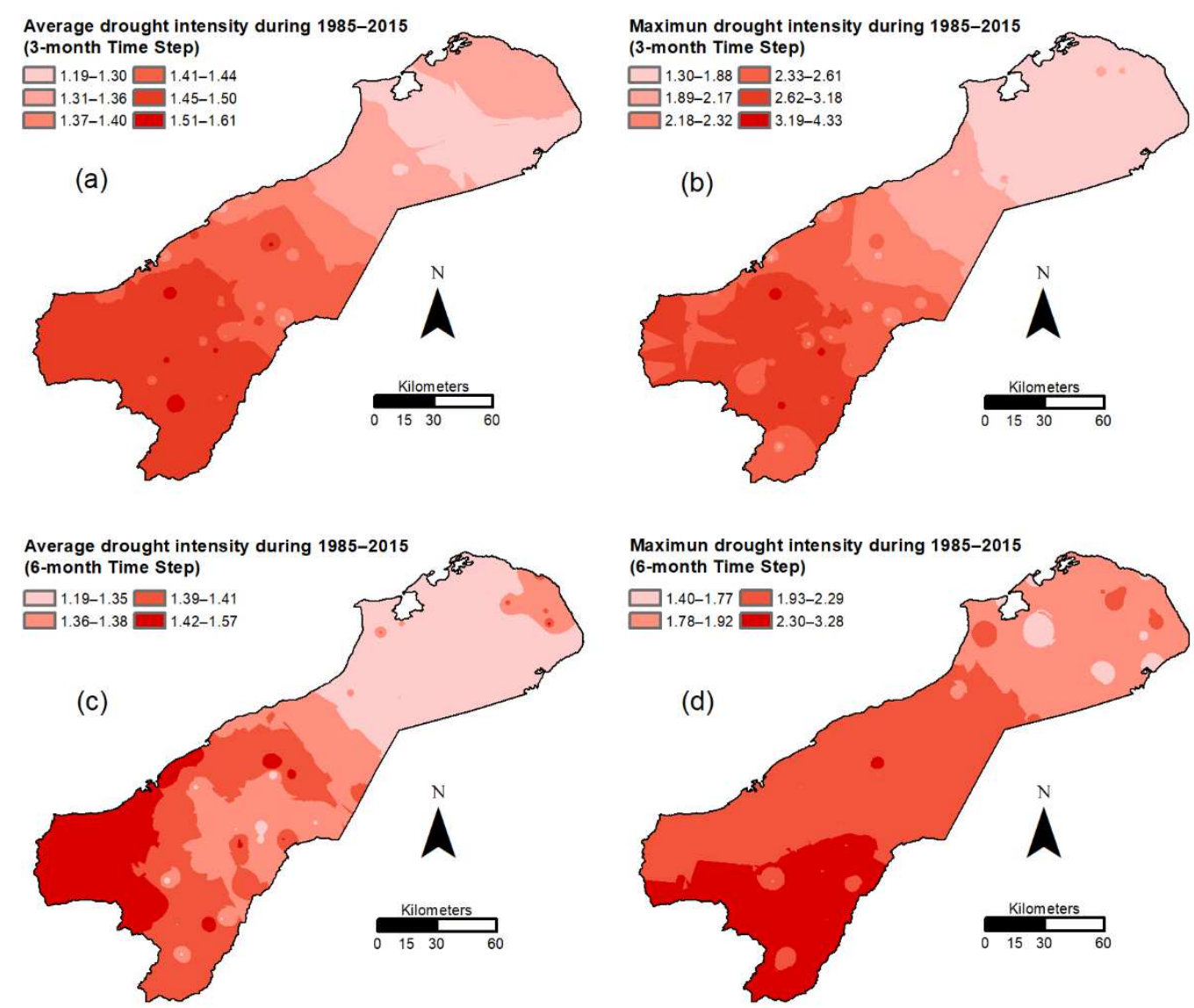

Fig. 7 Spatial distribution of drought intensity in the department of La Guajira during the period of 1985-

The previous results are indicative of a spatial correlation between the operational characteristics of the droughts that occurred in the department of La Guajira in the period of 1985-2015 for the analyzed temporal aggregations (SPI-3 and SPI-6). This indicates that areas with droughts of longer duration correspond to those areas that experience droughts of greater severity and intensity. Therefore, these are the areas of the department where water-dependent socioeconomic activities, such as agriculture and livestock activities, are more vulnerable (Contreras et al., 2020).

\subsection{Temporal drought trends SPI-3 and SPI-6}

The trend analysis of the time series of drought events that occurred in the department of La Guajira in the period of 1985-2015 through the MMK test at different levels of significance $\alpha(0.1,0.05,0.01$, and 0.001$)$ showed that the majority of meteorological stations in the department did not generally exhibit significant trends in the occurrence of drought events of greater magnitude in successive years of the study period, with percentages of $75.51 \%$ and $81.63 \%$ for SPI-3 and SPI-6, respectively (Fig. 8). However, the two SPI temporal aggregations revealed that some meteorological stations located in the central and southern areas of the department showed negative (decreasing) temporal trends at levels of significance between 0.1 and 0.01 , with a cumulative proportion of stations of $6.12 \%$ for SPI-3 and SPI-6. 
In contrast, positive (increasing) trends were observed in different areas of the department for events of greater magnitude that occurred in each year of the study period, especially in the northern, central, and southern areas at levels of significance between 0.05 and 0.001 and an accumulated proportion of meteorological stations of $18.36 \%$ for SPI-3 (Fig. 8). Similarly, positive trends were observed in the northern, eastern, and southern zones of the study area for SPI-6 in $12.24 \%$ of the meteorological stations at levels of significance between 0.05 and 0.001 .

This indicates that, although droughts are a natural and recurring element of the climate in the department of La Guajira due to the arid and semi-arid climate prevailing across much of its area, there are some periods of extreme drought and others during which water excesses can occur. This is governed by a climate variability phenomenon known as ENSO. The warm phase of ENSO (El Niño) reduces rainfall and increases air temperature, thus inducing droughts; whereas the cold phase ( La Niña) strengthens the rainy

(a) SPI-3

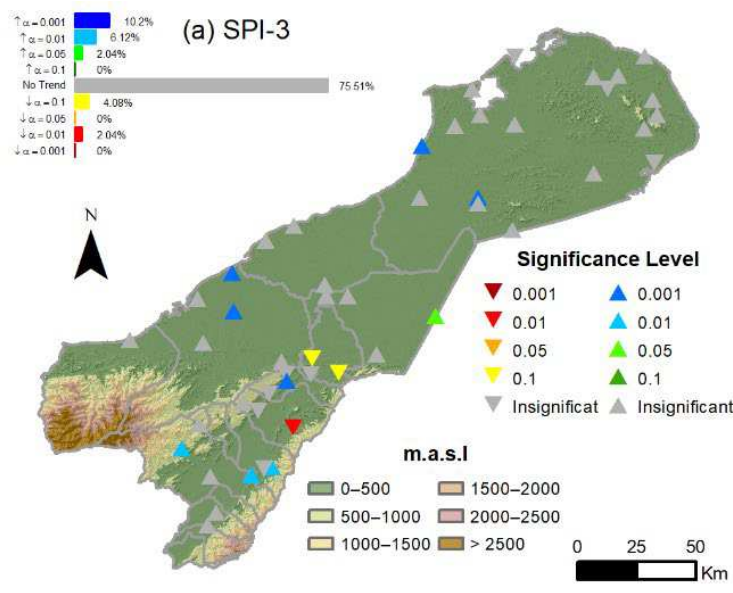

(b) SPI-6

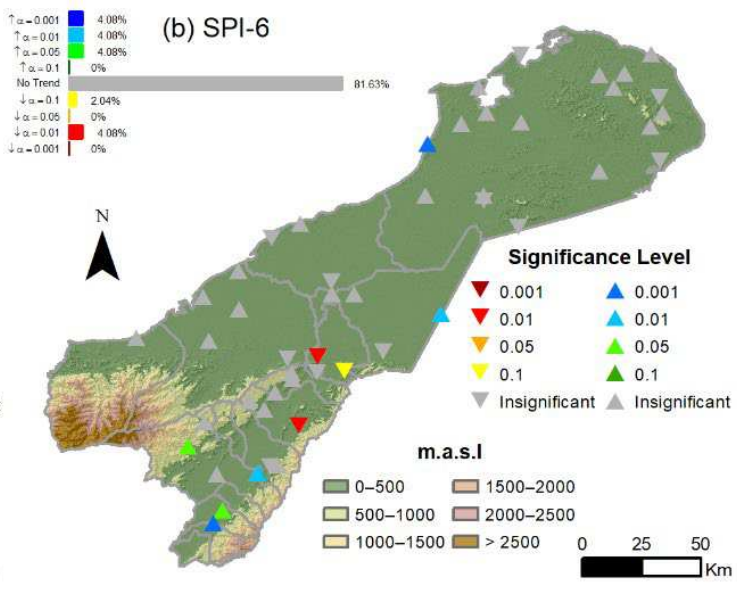

401

402

403

404

405

406

407

408

409

410

Fig. 8 Trend analysis at different levels of significance for all meteorological stations in the department of La Guajira during 1985-2015 for: (a) SPI-3 and (b) SPI-6

\section{Conclusions}

The findings of this study support the conclusion that droughts are recurrent events in the department of La Guajira due to the biophysical characteristics of the arid and semi-arid climate prevalent across most of its area. However, drought analysis during the period of 1985-2015 reveals that 1995-2004 was characterized by the highest occurrence of drought events, governed by climate variability phenomena such as ENSO in its warm phase (El Niño). 
Both the temporal aggregations, SPI-3 and SPI-6, used for assessing droughts in this study were able to accurately identify variations in rainfall for a given month, especially when a rainfall deficit considering the climatological mean constituted a drought event. SPI-6 was shown to be a better indicator of seasonal droughts in the department as it identifies rainfall fluctuations and the persistence of deficit conditions during a drought event.

417

In terms of the operational characteristics of droughts identified in the department of La Guajira for the period of 1985-2015, the results show that the southern, central, and western areas of the department experienced droughts of greater duration, severity, and intensity, and were also the areas where waterdependent socioeconomic activities such as agriculture and livestock were most vulnerable.

422

\section{Acknowledgments}

The authors are grateful to the University of La Guajira for the logistical and financial support provided through the research center, and to the Institute for Environmental Studies and Water Supply (INESAG) and the Pichihuel Research Group for their support and guidance during the different stages of research.

\section{Statements and Declarations}

All authors certify that they have no affiliations with or involvement in any organization or entity with any financial interest or non-financial interest in the subject matter or materials discussed in this manuscript.

431

\section{References}

Abramowitz M, Stegun IA (1965) Handbook of Mathematical Functions With Formulas, Graphs and Mathematical Tables (National Bureau of Standards Applied Mathematics Series No. 55). Journal of Applied Mechanics, Vol. 32, p. 239. https://doi.org/10.1115/1.3625776

Asadi Zarch MA, Sivakumar B, Sharma A (2015) Droughts in a warming climate: A global assessment of Standardized precipitation index (SPI) and Reconnaissance drought index (RDI). Journal of Hydrology, 526, 183-195. https://doi.org/10.1016/j.jhydrol.2014.09.071

Ashraf M, Routray JK (2015) Spatio-temporal characteristics of precipitation and drought in Balochistan Province, Pakistan. Natural Hazards, 77(1), 229-254. https://doi.org/10.1007/s11069-015-1593-1

Bedoya-Soto JM, Poveda G, Trenberth KE, Vélez-Upegui JJ (2019) Interannual hydroclimatic variability and the 2009-2011 extreme ENSO phases in Colombia: from Andean glaciers to Caribbean lowlands. Theoretical and Applied Climatology, 135(3-4), 1531-1544. https://doi.org/10.1007/s00704-018-2452-2

Begueria S, Serrano V, Sawasawa H (2017) SPEI: Calculation of Standardised PrecipitationEvapotranspiration index. R package version 1.7. A Case Study Birkoor Kortigiri Mandals. https://doi.org/10.1175/2009JCLI2909.1.http 
Belal AA, El-Ramady HR, Mohamed ES, Saleh AM (2012) Drought risk assessment using remote sensing and GIS techniques. Arabian Journal of Geosciences, 7(1), 35-53. https://doi.org/10.1007/s12517-0120707-2

Benitez, JB, Domecq RM (2014) Analysis of meteorological drought episodes in Paraguay. Climatic Change, 127(1), 15-25. https://doi.org/10.1007/s10584-014-1260-7

Bonaccorso B, Cancelliere A, Rossi G (2015) Probabilistic forecasting of drought class transitions in Sicily (Italy) using Standardized Precipitation Index and North Atlantic Oscillation Index. Journal of Hydrology, 526, 136-150. https://doi.org/10.1016/j.jhydrol.2015.01.070

Byun HR, Wilhite DA (1999) Objective quantification of drought severity and duration. Journal of Climate, 12(9), 2747-2756. https://doi.org/10.1175/1520-0442(1999)012<2747:OQODSA>2.0.CO;2

Caloiero $\mathrm{T}$ (2017) Drought analysis in New Zealand using the standardized precipitation index. Environmental Earth Sciences, 76(16). https://doi.org/10.1007/s12665-017-6909-x

460 Chang J, Li Y, Ren Y, Wang Y (2016) Assessment of precipitation and drought variability in the Weihe River Basin, China. Arabian Journal of Geosciences, 9(14). https://doi.org/10.1007/s12517-016-2638-9

462 Contreras D, Voets A, Junghardt J, Bhamidipati S, Contreras S (2020) The Drivers of Child Mortality 463 During the 2012-2016 Drought in La Guajira, Colombia. International Journal of Disaster Risk Science, 464 11(1), 87-104. https://doi.org/10.1007/s13753-020-00255-0

Corporación Autónoma Regional de La Guajira (CORPOGUAJIRA), I. de I. M. y C. "José B. V. de A.

466 (INVEMAR) (2012) Atlas Marino Costero de la Guajira. Retrieved from https://colaboracion.dnp.gov.co/CDT/Inversiones y finanzas pblicas/La Guajira 15-Ajustada.pdf

468 Dahal P, Shrestha NS, Shrestha ML, Krakauer NY, Panthi J, Pradhanang SM, Jha A, Lakhankar T (2016)

469 Drought risk assessment in central Nepal: temporal and spatial analysis. Natural Hazards, 80(3), 1913470 1932. https://doi.org/10.1007/s11069-015-2055-5

Ghosh S, Srinivasan K (2016) Analysis of Spatio-temporal Characteristics and Regional Frequency of Droughts in the Southern Peninsula of India. Water Resources Management, 30(11), 3879-3898. https://doi.org/10.1007/s11269-016-1396-5

474 Gómez J (2016) Estudio de Sequías en Colombia. In Instituto de Meteorología, Hidrología y Estudios 475 Ambientales - IDEAM.

476 Guajira, G. de La. (2012). Plan Departamental de Gestión del Riesgo de Desastres: La Guajira. Retrieved 477 from http://hdl.handle.net/20.500.11762/381

478 Guenang GM, Mkankam-Kamga F (2014) Computation of the standardized precipitation index (SPI) and 479 its use to assess drought occurrences in Cameroon over recent decades. Journal of Applied Meteorology and Climatology, 53(10), 2310-2324. https://doi.org/10.1175/JAMC-D-14-0032.1

481 Hamed KH, Rao AR (1998) A modified Mann-Kendall trend test for autocorrelated data. Journal of Hydrology, 204(1-4), 182-196. https://doi.org/10.1016/S0022-1694(97)00125-X

Hayes M, Svoboda M, Whilhite DA, Wilhite DA (1999) Monitoring drought using the standardized precipitation index. Drought: A Global Assessment Volume 1, 168-180. https://doi.org/http://dx.doi.org/10.1108/17506200710779521

He B, Lü A, Wu J, Zhao L, Liu M (2011) Drought hazard assessment and spatial characteristics analysis in China. Journal of Geographical Sciences, 21(2), 235-249. https://doi.org/10.1007/s11442-011-0841-x

He J, Yang XH, Li JQ, Jin JL, Wei YM, Chen XJ (2015) Spatiotemporal variation of meteorological droughts based on the daily comprehensive drought index in the Haihe River basin, China. Natural Hazards, 
Hong X, Guo S, Xiong L, Liu Z (2015) Spatial and temporal analysis of drought using entropy-based standardized precipitation index: a case study in Poyang Lake basin, China. Theoretical and Applied Climatology, 122(3-4), 543-556. https://doi.org/10.1007/s00704-014-1312-y

Hoyos I, Baquero-Bernal A, Jacob D, Rodríguez BA (2013) Variability of extreme events in the Colombian Pacific and Caribbean catchment basins. Climate Dynamics, 40(7-8), 1985-2003. https://doi.org/10.1007/s00382-012-1487-9

497 Hurtado, G. (2012). Sequía Meteorológica Y Sequía Agrícola En Colombia: Incidencia Y Tendencias.

498

499

500

501

502

503

504

505

506

507

508

509

510

511

512

513

514

515

516

517

518

519

520

521

522

523

524

525

526

527

528

529

530

531

532

Husak G, Michaelsen J, Funk C (2007) Use of the gamma distribution to represent monthly rainfall in Africa for drought monitoring applications. International Journal of Climatology, 27(December 2007), 935944. https://doi.org/10.1002/joc.1441

IDEAM (2016) Estudio de sequias en colombia.

Influence C, Henrique B, Michiko C, Okawa P (2017) Application of a Standardized Precipitation Index for Meteorological Drought Analysis of the Semi-Arid Climate Influence in Minas Gerais, Brazil. Hydrology, 4(2), 26. https://doi.org/10.3390/hydrology4020026

Ionita M, Scholz P, Chelcea, S (2016) Assessment of droughts in Romania using the Standardized Precipitation Index. Natural Hazards, 81(3), 1483-1498. https://doi.org/10.1007/s11069-015-2141-8

Karabulut M (2015) Drought analysis in Antakya-Kahramanmaraş Graben, Turkey. Journal of Arid Land, 7(6), 741-754. https://doi.org/10.1007/s40333-015-0011-6

Livada I, Assimakopoulos VD (2007) Spatial and temporal analysis of drought in Greece using the Standardized Precipitation Index (SPI). Theoretical and Applied Climatology, 89(3-4), 143-153. https://doi.org/10.1007/s00704-005-0227-z

Lloyd-Hughes B, Saunders MA (2002) A drought climatology for Europe. International Journal of Climatology, 22(13), 1571-1592. https://doi.org/10.1002/joc.846

Loaiza-Cerón W, Carvajal-Escobar Y, De Souza RVA, Kayano MT, López NG (2020) Spatio-temporal analysis of the droughts in Cali, Colombia and their primary relationships with the El Nino-Southern Oscillation (ENSO) between 1971 and 2011. Atmosfera, 33(1), 51-69. https://doi.org/10.20937/ATM.52639

Loaiza-Cerón W, Carvajal-Escobar Y, Baquero-Montoya OL (2015) Índice estandarizado de precipitación (SPI) para la caracterización de sequías meteorológicas en la cuenca del río Dagua-Colombia. Estudios Geográficos, 76(279), 557-578. https://doi.org/10.3989/estgeogr.201520

Logan KE, Brunsell NA, Jones AR, Feddema JJ (2010) Assessing spatiotemporal variability of drought in the U.S. central plains. Journal of Arid Environments, 74(2), 247-255. https://doi.org/10.1016/j.jaridenv.2009.08.008

Luetkemeier R, Stein L, Drees L, Liehr S (2017) Blended Drought Index: Integrated Drought Hazard Assessment in the Cuvelai-Basin. Climate, 5(3), 51. https://doi.org/10.3390/cli5030051

Manatsa D, Mukwada G, Siziba E, Chinyanganya T (2010) Analysis of multidimensional aspects of agricultural droughts in Zimbabwe using the Standardized Precipitation Index (SPI). Theoretical and Applied Climatology, 102(3), 287-305. https://doi.org/10.1007/s00704-010-0262-2

Manikandan M, Tamilmani D (2015) Spatial and Temporal Variation of Meteorological Drought in the Parambikulam-Aliyar Basin, Tamil Nadu. Journal of The Institution of Engineers (India): Series A, 96(3), 177-184. https://doi.org/10.1007/s40030-015-0121-3

Mann HB (1945) Nonparametrics Tests Against Trend. The Econometric Society, 13(3), 245-259.

Mansouri-Daneshvar MR, Bagherzadeh A, Khosravi M (2013) Assessment of drought hazard impact on wheat cultivation using standardized precipitation index in Iran. Arabian Journal of Geosciences, 6(11), 4463-4473. https://doi.org/10.1007/s12517-012-0695-2 
538 Mayorga R, Hurtado G (2006) La Sequía En Colombia Documento Técnico De Respaldo a La Información 539 En La Página Web Del Ideam. Instituto de Meteorología, Hidrología y Estudios Ambientales - IDEAM, 54066.

541 Mckee TB, Doesken NJ, Kleist J (1993) The relationship of drought frequency and duration to time scales.

542 AMS 8th Conference on Applied Climatology, (January), 179-184. https://doi.org/citeulike-article543 id: 10490403

544 Mendoza M, Puche N (2007) Evaluación de la ocurrencia de sequía en localidades de Venezuela Drought 545 occurrence evaluation in localities of Venezuela Introducción. Rev. Fac. Agron, 24, 661-678.

546 Mishra AK, Singh, VP (2010) A review of drought concepts. Journal of Hydrology, 391(1-2), 202-216. 547 https://doi.org/10.1016/j.jhydrol.2010.07.012

548 Mitra S, Srivastava P (2017) Spatiotemporal variability of meteorological droughts in southeastern USA.

549 Natural Hazards, 86(3), 1007-1038. https://doi.org/10.1007/s11069-016-2728-8

550 Nam WH, Hayes MJ, Svoboda MD, Tadesse T, Wilhite DA (2015) Drought hazard assessment in the 551 context of climate change for South Korea. Agricultural Water Management, 160, 106-117. 552 https://doi.org/10.1016/j.agwat.2015.06.029

553 Palmer WC (1965) Meteorological Drought. U.S. Weather Bureau, Res. Pap. No. 45, p. 58. Retrieved from $554 \mathrm{https} / / /$ www.ncdc.noaa.gov/temp-and-precip/drought/docs/palmer.pdf

555 Parker DJ, Priest SJ, Tapsell SM (2009) Understanding and enhancing the public's behavioural response 556 to flood warning information. Meteorological Applications, 114(January), 103-114. 557 https://doi.org/10.1002/met

558 Rahman, M. R., \& Lateh, H. (2016). Meteorological drought in Bangladesh: assessing, analysing and 559 hazard mapping using SPI, GIS and monthly rainfall data. Environmental Earth Sciences, 75(12). $560 \mathrm{https} / / /$ doi.org/10.1007/s12665-016-5829-5

561 Rivera del Río R, Crespo-Pichardo G, Arteaga-Ramírez R, Quevedo-Nolasco A (2007) Temporal and 562 Spatial Behavior of Drought in the State of Durango , Mexico. Terra Latinoamericana, 25, 383-392.

563 Rivera J, Penalba O (2014) Trends and Spatial Patterns of Drought Affected Area in Southern South 564 America. Climate, 2(4), 264-278. https://doi.org/10.3390/cli2040264

565 Rojas LPT, Díaz-Granados M (2018) The construction and comparison of regional drought severity566 duration-frequency curves in two Colombian River basins-study of the Sumapaz and Lebrija Basins. Water 567 (Switzerland), 10(10). https://doi.org/10.3390/w10101453

568 Santos CAG, Brasil-Neto RM, Passos JSA, da Silva RM (2017) Drought assessment using a TRMM569 derived standardized precipitation index for the upper São Francisco River basin, Brazil. Environmental 570 Monitoring and Assessment, 189(6). https://doi.org/10.1007/s10661-017-5948-9

571 Shahid S, Behrawan H (2008) Drought risk assessment in the western part of Bangladesh. Natural Hazards, 572 46(3), 391-413. https://doi.org/10.1007/s11069-007-9191-5

573 Sönmez FK, Kömüscü AÜ, Erkan A, Turgu E (2005) An analysis of spatial and temporal dimension of 574 drought vulnerability in Turkey using the standardized precipitation index. Natural Hazards, 35(2), 243575 264. https://doi.org/10.1007/s11069-004-5704-7

576 Thom HCS (1966) Some methods of climatological analysis. WMO Technics/Note, 81, 55.

577 Thomas T, Jaiswal RK, Nayak PC, Ghosh NC (2014) Comprehensive evaluation of the changing drought 578 characteristics in Bundelkhand region of Central India. Meteorology and Atmospheric Physics, 127(2), 579 163-182. https://doi.org/10.1007/s00703-014-0361-1 
580 Touchan R, Funkhouser G, Hughes MK, Erkan N (2005) Standardized precipitation index reconstructed 581 from Turkish tree-ring widths. Climatic Change, 72(3), 339-353. https://doi.org/10.1007/s10584-005$582 \quad 5358-9$

583 Vicente-Serrano SM, Beguería S, López-Moreno JI (2010) A multiscalar drought index sensitive to global 584 warming: The standardized precipitation evapotranspiration index. Journal of Climate, 23(7), 1696-1718. 585 https://doi.org/10.1175/2009JCLI2909.1

586 Yan Z, Zhang Y, Zhou Z, Han N (2017) The spatio-temporal variability of droughts using the standardized 587 precipitation index in Yunnan, China. Natural Hazards, 88(2), 1023-1042. https://doi.org/10.1007/s11069$588 \quad 017-2904-5$

589 Yevjevich V (1967) An objective approach to definitions and investigations of continental hydrologic 590 droughts. Journal of Hydrology, 7(3), 353. https://doi.org/10.1016/0022-1694(69)90110-3

591 Yu X, He X, Zheng H, Guo R, Ren Z, Zhang D, Lin J (2014) Spatial and temporal analysis of drought risk 592 during the crop-growing season over northeast China. Natural Hazards, 71(1), $275-289$. 593 https://doi.org/10.1007/s11069-013-0909-2

594 Yuan Z, Yan DH, Yang ZY, Yin J, Yuan Y (2015) Temporal and spatial variability of drought in Huang595 Huai-Hai River Basin, China. Theoretical and Applied Climatology, 122(3-4), 755-769. 596 https://doi.org/10.1007/s00704-014-1332-7

597 Zuo D, Cai S, Xu Z, Li F, Sun W, Yang X, Kan, G, Liu P (2018) Spatiotemporal patterns of drought at 598 various time scales in Shandong Province of Eastern China. Theoretical and Applied Climatology, 131(1599 2), 271-284. https://doi.org/10.1007/s00704-016-1969-5 